\title{
SEALED AND DELIVERED: A THEORY OF UNILATERAL TRANSFER AT COMMON LAW
}

\author{
STÉPHANE SÉRAFIN
}

\begin{abstract}
Some view the sealed instrument as a relic of the common law that is incompatible with modern contract law theory. However, the fact remains that the seal is a valid method to create a binding agreement in Canadian law. This article proposes a theoretical justification of the seal that better places it within contract theory. The author argues that instead of understanding seals as analogous to a consideration-based promise, we should understand seals as analogous to an executed gift. Through this analogy, the seal can be understood as an agreement that creates an immediate and unilateral transfer of rights.
\end{abstract}

\section{TABLE OF CONTENTS}

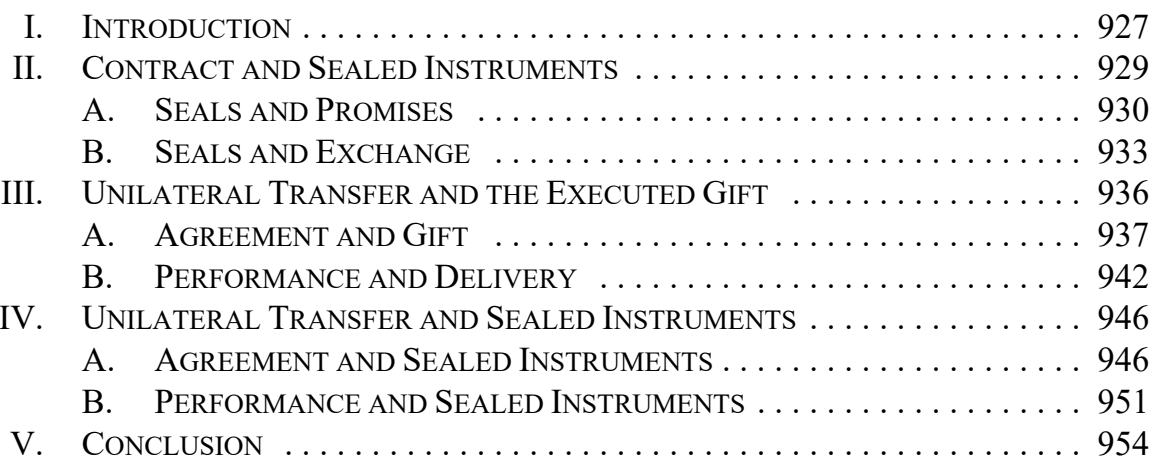

\section{INTRODUCTION}

In his influential account of contract as promise, Charles Fried identifies the traditional common law requirement of consideration as superfluous at best, and contrary to the promissory nature of contract at worst. ${ }^{1} \mathrm{He}$ is not alone in this regard. Many, if not most, Anglo-American contract theorists share his opposition to the requirement of consideration on similar grounds, even as they recognize its continued relevance as a matter of positive law. ${ }^{2}$

If, however, the theoretical grounding for consideration appears precarious, then the apparent possibility of circumventing the rule by means of a sealed instrument - the socalled "promise under seal," which is enforceable as a legally binding contract even in the absence of consideration - has proven even more controversial. This much is reflected in

Assistant Professor, University of Ottawa, Faculty of Law, Common Law Section; BSocSc, JD, LLL (University of Ottawa); LLM (University of Toronto). This article presents a substantially revised version of the argument originally defended in the author's LLM thesis. The author wishes to thank Peter Benson for his feedback on the initial argument, and would further like to thank three anonymous reviewers for their comments on earlier versions of the article.

Charles Fried, Contract as Promise: A Theory of Contractual Obligation (Cambridge, Mass: Harvard University Press, 1981) at 35-36.

$2 \quad$ As Stephen Smith has put it, "[t] here is probably no rule in the common law of contract that has been subject to more criticism than the consideration rule": Stephen A Smith, Contract Theory (Oxford: Oxford University Press, 2004) at 215. 
the attitude actually taken towards the seal in practice: while a number of jurisdictions have contemplated removing the need for consideration, the use of sealed instruments as an alternative to consideration-based contracts has effectively been abolished by statute in much of the United States. ${ }^{3}$ Moreover, even those authors who defend consideration as an innate feature of contract or on external policy grounds have tended to dismiss the importance of the seal by framing it as a largely historical feature of the positive common law. ${ }^{4}$

Against this backdrop, this article proposes an alternative, and arguably more defensible, justification for the role of sealed instruments in common law jurisdictions. ${ }^{5}$ Building on Alan Brudner's argument, I will suggest that the effects of these devices should not be understood by analogy to consideration-based promises, or even to bare promises generally, but as the result of an agreement that effects a unilateral transfer of rights - which is to say, a transfer from one party to another, without an expectation of return - in a manner analogous to the executed gift. ${ }^{6}$ I will further propose that this second type of agreement can be understood to arise simultaneously with, and is mediated through, its immediate performance in the delivery of sealed instrument by the instrument-maker to its intended recipient. It is in this sense that the use of the sealed instrument - whether it pertains to the transfer of in rem rights or an ostensibly in personam right to demand future performance can accordingly be understood not as a means of granting legal effect to a prior promise, but rather as a means of rendering the immediate performance of an agreement through the medium of the sealed instrument itself.

My argument will proceed in three parts. Part II of this article will begin by briefly examining the place of agreements concluded by means of sealed instruments within existing theoretical accounts of the common law of contracts. As I will argue, both promissory defences of contract and more narrowly exchange-based theories point to, or at least allow for, an explanation of some of the sealed instrument's effects in the manner just proposed. On this view, the seal is tied not so much to the enforcement of promises to tender performance at some point in the future - even if it can be used to generate what effectively

3 On the abolition of sealed instruments and its recognized alternatives in various American states, see Eric Mills Holmes, "Stature and Status of a Promise under Seal as a Legal Formality" (1993) 29:4 Willamette L Rev 617 at 663-65. But see The American Law Institute, Restatement of the Law Second: Contracts 2d, vol 1 (St. Paul, Minn: American Law Institute, 1981) at \$95(1) [Restatement (Second)] ("[i]n the absence of statute a promise is binding without consideration if (a) it is in writing and sealed; and (b) the document containing the promise is delivered; and (c) the promisor and promisee are named in the document or so described").

4 See e.g. Ernest J Weinrib, The Idea of Private Law (Oxford: Oxford University Press, 2012) at 138, n 30, citing Peter Benson, "Contract Law and Corrective Justice" (1992) [unpublished] [Benson, "Contract Law"]; Lon L Fuller, "Consideration and Form" (1941) 41:5 Colum L Rev 799 at 823 [Fuller, "Consideration and Form"].

5 The term "sealed instrument" is used in this article as a neutral shorthand for all formal or solemn agreements that have historically required the application of a seal, without regard to whether the seal remains required to give effect to some or all these documents in particular jurisdictions: see e.g. Law of Property (Miscellaneous Provisions) Act 1989 (UK). It can thus be understood to encompass not only promises made under seal, but also the term "deed," which is typically (though perhaps not exclusively) used to designate those sealed instruments that are used to convey interests in property: see e.g. Friedmann Equity Developments Inc v Final Note Ltd, 2000 SCC 34 at para 50 [Friedmann].

6 See Alan Brudner with Jennifer M Nadler, The Unity of the Common Law, 2nd ed (Oxford: Oxford University Press, 2013) at 199.

By contrast to Alan Brudner, my argument in this respect will draw not so much from Hegel, but rather from Immanuel Kant's distinction between contracts (or agreements) of future performance and those that serve to effect an immediate transfer of property rights (for example, rights properly enforceable against third parties): see Immanuel Kant, The Metaphysics of Morals, 2nd ed by Mary Gregor (Cambridge, UK: Cambridge University Press, 1996) at 60-61. 
amount to promissory obligations - but instead to executed agreements that effect an immediate and unilateral transfer of rights.

Part III will then examine what can probably be taken as the paradigmatic case of unilateral transfer at common law: that is, the executed gift that is completed, and thus rendered enforceable, by means of delivery. ${ }^{8}$ My objective will be to show that the enforcement of a completed gift is not dependent on promising, but rather on the immediate performance of an entirely separate, self-contained agreement through the act of delivery. This framework, in turn, allows us to understand why a gift that is not enforceable as an obligation may nonetheless be enforced as a fully executed transfer of rights over gift property.

Finally, Part IV of this article will build on the above conclusions to argue that the enforcement of agreements concluded by way of sealed instrument is consistent with the rationale behind the enforcement of executed gifts. Just as delivery mediates offer and acceptance through simultaneous performance — serving as the means through which all three occur, or are exchanged, at the same time — so too does the sealed instrument. By accepting the instrument, its recipient accepts not only the instrument-maker's intention to transfer rights, but also her immediate, simultaneous performance of the agreement through the actual transfer of the rights set out in the document under seal.

\section{CONTRaCt AND SEALED InSTRUments}

Since my argument in this article supposes that the role of sealed instruments is better understood outside the domain of contract law, the first question to be addressed pertains to whether, and to what extent, the effects of these devices can in fact be accounted for within contract law proper. Perhaps the most straightforward argument against this possibility is the characterization of the seal as an anachronism that cannot be justified by modern commercial practice, even if alternative formalities such as consideration might be explained on policy or other grounds. As Lon Fuller puts it, for example, "[d]oubt may legitimately be raised ... whether there will be any place in the future for what may be called the 'blanket formality,' the formality which, like the seal, suffices to make any kind of promise, not immoral or illegal, enforceable."

While I do not intend to discount the possibility that the use of sealed instruments might nonetheless be reconciled with contract as a policy or evidentiary matter, my focus in this article is comparatively narrower, being limited to whether these devices can be explained as an essential feature of contract itself. To this end, I begin by examining two competing views of what a "contract" actually entails in common law jurisdictions, the first corresponding to what we might term "promissory" theories of contract, understood here to refer broadly to those theories that do not insist on the role of consideration or formalities as

\footnotetext{
8 The gift completed in this way can of course be distinguished from the promise of gift, which is generally understood to be unenforceable at common law: see e.g. Dalhousie College v Boutilier Estate, [1934] SCR 642 at 645-46.

$9 \quad$ Fuller, "Consideration and Form," supra note 4 at 823. Contrast Friedmann, supra note 5 at para 49 ("[t]here are many rules in contract and property law which are historical, technical and which no longer appear to have any modern day rationale. However ... to abolish the sealed contract rule on the ground that it is technical and anachronistic could have the effect of creating uncertainty as to the validity of these other technical rules which do not appear to have a modern day rationale"); SM Waddams, The Law of Contracts, 6th ed (Toronto: Canada Law Book, 2010) at paras 171-72.
} 
essential requirements of contractual validity. ${ }^{10}$ The second set of theories, by contrast, corresponds to what might be termed an "exchange-based" understanding of the common law of contracts: it is rooted not in promises or injury, but in the provision of consideration in the form of an exchange by both parties to the transaction. ${ }^{11}$ As I will argue, each of these sets of theories points in its respective way to an explanation for the effects of the sealed instrument that is to be found outside of the realm of contract per se - or, at least, outside of the realm of contract as it is typically understood in common law sources.

\section{A. Seals and Promises}

Starting with promissory theories of contract, this class can again be understood for the purposes of this article to encompass those theories that reject the strict relevance of formalities of any kind to the question of whether a "contract" has been concluded. It accordingly includes both strictly promissory theories and reliance-based theories of contract insofar as each subset remains focused on the act of promising - and the consequences that follow from it - as the core justification for the enforcement of contracts. ${ }^{12}$ The generality of the framework purports to account in both cases for the conditions that will allow the enforcement of any and all promises - which is to say, of any and all contractual obligations to perform, or else to compensate the promisee for the promisor's failure to perform. In both cases, the generality of this framework can further be taken to exclude the necessity of contractual formalities like the seal as a matter of strict theory, if not necessarily in practice.

If we are to attempt to find some justification for the necessity of sealed instruments under either of these views of contract, then it appears from the outset that we will need to look elsewhere, outside the law of contracts proper, and to other, related types of transactions in particular. Such is, in fact, the conclusion that appears when we examine these theories more closely. In the case of strictly promissory theories, it follows from the foregoing that the enforcement of even gratuitous promises should not be denied in principle for lack of consideration, which, to paraphrase Fried, can again be understood as either incompatible with the promissory nature of contract, or else outright contradictory to its basis in the act of promising. ${ }^{13}$ The same can generally be taken to hold true of the requirement of delivery attaching to the enforcement of a gift, at least insofar as it pertains to the enforcement of a gift qua future obligation to render performance - that is, as a gratuitous promise. Since there are no external policy reasons that justify the enforcement of executed gift over

10 The views of three authors in particular will be considered here, namely Charles Fried, Stephen Smith, and Patrick Atiyah; while diverging significantly in terms of their overall approach to contracts, they can be taken to share an understanding of the seal that is representative of many other authors as well. See Smith, supra note 2 at 221; the three authors considered in this article as part of the discussion of exchange-based theories of contract, namely Peter Benson, Ernest Weinrib, and Alan Brudner, can thus be taken, contra Smith and others, to defend this view of contract from the criticism that has been levied against it. While all three advance what Smith calls a "transfer theory" of contract, I note that not all transfer theorists appear to embrace a strict view of the consideration requirement, and some might even fall within the promissory category as I have defined it in this article: see most notably Randy E Barnett, "A Consent Theory of Contract" (1986) 86:2 Colum L Rev 269 at 311.

12 Contrast Smith, supra note 2 at 80 ("if the aim of contract law is to protect the reliance interest, there seems to be no good reason why reliance that is induced without a promise should be ignored"). The chief difference between the two, namely that the former views the voluntary act of promising as a source of rights, whereas the latter understands liability to be imposed upon the parties from without, is, in the author's view, not strictly relevant for the present discussion of sealed instruments.

13 As Fried puts it, "the doctrine of consideration offers no coherent alternative basis for the force of contracts, while still treating promise as necessary to it": Fried, supra note 1 at 38. 
gratuitous promises, the promissory principle appears to require that the bare promise to give be enforceable as a contract, even where delivery has not yet occurred. ${ }^{14}$

None of the foregoing is particularly controversial from the perspective of a strictly promissory theory of contract. At best, we may affirm that these requirements remain relevant in practice as indicia of contractual intent, in a manner that is largely reminiscent of Lon Fuller's classic policy-based defence of the consideration rule. ${ }^{15}$ The same can be said about the attitude of promissory theories towards sealed instruments themselves, which Stephen Smith neatly summarizes: the problem with this latter requirement from the perspective of a strictly promise-based theory is the same as with the requirement of consideration, in that they both appear as formalities that are imposed upon, but not strictly required by, a rights-based theory of contract. ${ }^{16}$ We can add here that while it may nonetheless be possible to defend the role played by certain formalities on a purely evidentiary basis within promise theory, this possibility is even more suspect in the case of sealed instruments given the aforementioned doubts as to their continued relevance as a practical, rather than simply theoretical, matter. ${ }^{17}$ Fried in particular appears to draw on these when formulating his critique of the seal. As opposed to consideration, which he rejects in principle even as he accepts its role as a matter of positive common law, his characterization of the seal is as "an anachronistic relic" whose withering away has left "the doctrine of consideration as very much the norm." $" 18$

A similar set of issues appears to arise when we focus not on the relevance of the seal to the act of promising, but rather to the injury suffered by the promisee in reliance on such a promise. To take what is perhaps still the most prominent version of a reliance theory of contract - the version espoused by Patrick Atiyah - this theory can be understood to anchor contractual liability in the question of whether a promisee relied on, or might have been reasonably entitled to rely on, the promise to her detriment. ${ }^{19}$ Such a theory should be at least implicitly hostile to the effects of contractual formalities in general, and to the seal in particular, for much the same reasons as those outlined above. Since a promisee may well suffer detrimental reliance in the absence of either consideration as exchange or the use of a sealed instrument, these requirements appear contrary to the reliance-based nature of contract to the extent that they are imposed as a substantive condition of liability. ${ }^{20}$ The main

$14 \quad$ Ibid at 37. As I will suggest below, however, Fried's conclusion here need not be determinative of the value of delivery in respect of a completed transfer of property rights.

15 This is the solution that Smith ultimately adopts in his own work: see Smith, supra note 2 at 65 ("Formalities are justified, in broad terms, on the basis that they facilitate the expression and proof of contracting parties' intentions.... As such, while they are not required by reliance, transfer, or promissory theories, they are not inconsistent with the substantive sources of liability that are the focus of these theories" [emphasis in original]).

16 Ibid at 151,232

17 As suggested above, these doubts have largely prevailed in the United States, where they have led to the general abolition of the seal as an alternative to consideration; similar doubts have been expressed (and considered by courts) in other jurisdictions, including in Canada: see most notably Friedmann, supra note 5 at para 49 .

18 Fried, supra note 1 at 28-29.

19 One of the main tenets of this theory thus lies in its recasting the notion of consideration in a manner that makes it largely synonymous with the promisee's reliance on - and thus the existence of an injury caused by - a particular promise: see PS Atiyah, The Rise and Fall of Freedom of Contract (Oxford: Clarendon Press, 1979) at 184-86. See also Grant Gilmore, The Death of Contract (Columbus: Ohio State University Press, 1974) at 19-21.

20 The potential availability of estoppel or reliance-based redress even where these requirements have not been met would appear to be a point in favour of reliance theories in general, though this does not of course provide an explanation for why either consideration or the seal might permit the enforcement of promises even where reliance has not occurred. 
difference with proper promise theories is the substantive irrelevance of formalities like the seal to the question of whether the promisee suffered injury, rather than to whether the promisor intended the promise. At best, we can surmise that the role of the seal should likewise be limited to providing an indication of the types of promises that are more likely to result in detrimental reliance or the conferral of an undue benefit upon their breach. ${ }^{21}$

In this context, it becomes apparent that neither strictly promissory nor reliance-based theories of contract are properly capable of accounting for the effects that the common law ascribes to sealed instruments, or are at least incapable of doing so as a matter of strict theory. The views of both Fried and Smith in particular do not reflect the attitude of the positive common law with respect to the enforcement of promises: the latter still clearly requires the provision of something like consideration as exchange or compliance with the form of a sealed instrument before it will enforce a promise as a valid contract. ${ }^{22}$ In order to maintain the promissory or injury-focused ideal of contract, it thus appears that both sets of theories must dismiss the effects of the seal as either a purely evidentiary formality, or else as a historical choice of the positive common law that is not strictly relevant to any proper theory of contract. ${ }^{23}$

That said, there remains one alternative possibility even on this view of contract that might allow us to account at least in part for the effects of sealed instruments - and to do so, for that matter, in a way that may account for their theoretical necessity as a precondition for the enforcement of at least certain kinds of transactions. For while there may be no substantive rationale that can support their relevance to the question of whether a promise is seriously intended or whether the promisee should be compensated for her losses, neither of these theories accounts for - nor do they attempt to account for - the question of whether formalities might be relevant to another related issue such as the transfer or conveyance of property rights.

Indeed, Fried's promissory theory of contract, like that of Smith's version of promise theory and even Atiyah's reliance theory, is primarily meant to explain the enforcement of promises - which is to say, to answer the question of why and when an executory agreement ought to bind someone to render performance at some point in the future. ${ }^{24}$ Smith in particular goes so far as to completely exclude even instantaneous transfers of property made in the context of an exchange from his conception of contract, on the basis that they do not result from promissory obligations. In his view, these transactions should more properly be classified alongside executed gifts and wills as non-contractual transfers of property. ${ }^{25}$

${ }_{21}$ See e.g. Atiyah, supra note 19 at 4 ("[m]uch of this book is based on the conviction that this traditional attitude to promise-based obligations is misconceived, and that the grounds for the imposition of such liabilities are, by the standards of modern values, very weak compared with the grounds for the creation of benefit-based and reliance-based obligations"). That the use of a formal instrument or the affixing of a seal is not necessarily or even typically associated with the presence of these consequences is supported by their almost complete omission from Atiyah's account of contract.

22 See Fried, supra note 1 at 37 ("I conclude that the life of contract is indeed promise, but this conclusion is not exactly a statement of positive law"); Smith, supra note 2 at 65.

Fried, ibid; Smith, ibid.

This much is evident from the opening paragraph of Fried's work, in which he writes that "[t]he promise principle, which in this book I argue is the moral basis of contract law, is that principle by which persons may impose on themselves obligations where none existed before": Fried, ibid at 1. See also Smith, ibid at 57; Atiyah, supra note 19 at 4.

25 Smith, ibid at 62-63. 
This last idea can be developed into a more complete explanation for the effects ascribed to sealed instruments, and may in fact amount to the only means by which the operation of these devices can be at least partly reconciled with a promissory understanding of contract. It is precisely this objective that I will pursue in Parts III and IV of this article. Before turning to this line of argument, however, I want to briefly examine an alternative understanding of the common law contract, which, although pointing to the conceptual difficulties posed by sealed instruments in other ways, also suggests this same explanation for their operation.

\section{B. SEALS AND EXCHANGE}

Having concluded that a defence of contract as a promise requires that the sealed instruments be recast as a purely evidentiary formalities, or else that the effects ascribed to them be abolished entirely, the question that now arises pertains to the lessons that might be drawn when we attempt to fit these devices into an alternative, exchange-based view of contract centred on the requirement of bargain consideration.

As with the promissory theories examined above, it is apparent here that an exchangebased conception of contract faces at least one major obstacle of its own, even on its face. Specifically, while the theory purports to exclude the enforcement of gratuitous promises, it does not - and perhaps cannot - account for the various forms of agreement that the common law does recognize and enforce even in the absence of consideration as exchange. The list of such arrangements is relatively long, and potentially includes gifts, bailments, and certain specialty forms of transaction such as those concluded by means of negotiable instrument, among others. ${ }^{26}$ This list also includes the particular device that forms the core subject of this article - the sealed instrument - which at least appears to allow for the creation of an enforceable executory agreement or "contract" without the need for consideration.

What appears to distinguish the sealed instrument from these other apparent exceptions to consideration, then, and makes it particularly challenging for the exchange-based conception of contract, is that it appears to allow for the conclusion of any kind of agreement in a legally enforceable manner without consideration: it is, to borrow Fuller's expression, a "blanket formality" that "suffices to make any kind of promise, not immoral or illegal, enforceable." 27 For a theory of contract rooted in the centrality of consideration as an exchange between two parties, it is difficult to see how this rule can be circumvented simply by having the parties to a transaction comply with the form of a special written instrument. Contract as exchange simply cannot offer an explanation, let alone a justification, for these kinds of ostensibly valid and generally enforceable agreements.

As against this state of affairs, the solution adopted by most modern proponents of contract as exchange has thus been to evict the agreement concluded under seal from the contractual domain entirely, and to ground its capacity to generate enforceable obligations elsewhere. Such is precisely the view of sealed instruments that Peter Benson adopts, for

26 The problems presented by these classes of agreement have been known since at least the nineteenth century: see Erwin Grueber, "A Difficulty in the Doctrine of Consideration" (1886) 2:1 Law Q Rev 33 at 37 (concluding that arrangements corresponding to the Roman law depositum and mandatum and to the related common law notions of bailment and agency are enforceable even without consideration). Fuller, "Consideration and Form," supra note 4 at 823. 
example, in his own defence of contract as exchange. As he explains, the relationship between the parties to a consideration-based contract is "not reducible to, but is genuinely distinct from, the idea of delivery (or other acts) in the case of a sealed document." 28 To this, he later adds that the various kinds of ostensibly contractual liability recognized by the common law - whether rooted in the provision of consideration, the use of a seal, or delivery in the case of a gift - each entail "a definite and distinct kind of legal relation and these relations are constituted by different sorts of acts of the parties reasonably interpreted." ${ }^{29}$ Ernest Weinrib is perhaps more explicit in terms of what Benson's distinction, which he adopts as his own, is meant to imply:

Since I am looking at contract law as the juridical embodiment of corrective justice, the validity of unilateral
promises under seal is not relevant. As Benson points out in "Contract Law and Corrective Justice," promises
under seal do not reflect the normative contours of transactions as such; rather, they are creations of positive
law, which for instrumental purposes makes available a means of juridically binding oneself. Hobbes's
discussion of contract implicitly illustrates Benson's point. Hobbes assumes that the natural law of contract,
which is used to emerge from the state of nature, incorporates the doctrine of consideration, not the doctrine
of seals, presumably because seals, being creations of positive law, have no validity in the state of nature.

In other words, both Benson and Weinrib appear to frame the agreement concluded under seal as a distinct kind of transaction from the exchange-based contract. While the former reflects a natural and intrinsically defensible legal relationship between two parties, the seal is dismissed as a doctrine that emerged on a largely ad hoc historical basis, as a practical determination made by the positive common law, rather than directly on the basis of any higher order principle. Echoing in this respect both Fuller and at least some of the promise theorists examined above, we might even conclude from this account that the possibility of concluding agreements by means of a sealed instrument should be abolished altogether.

That said, there are also at least two objections that can be raised against the foregoing conclusions, and that together point to the continued difficulty the seal continues to play for Benson and Weinrib's respective understandings of contract. The first, simply, is that the exclusion of agreements under seal as improper contracts appears to be rooted in a certain degree of circularity: exchange-based agreements are proper contracts because they correspond to the ideal of corrective justice, thus affirming the centrality of corrective justice to contract law, whereas agreements concluded under seal are to be excluded because they do not correspond to this same ideal. There is an element lacking in the above exposition that should allow us to understand why the former class of agreement is more properly deserving of the contractual label in the first place. ${ }^{31}$

28 Peter Benson, "The Idea of Consideration" (2011) 61:2 UTLJ 241 at 246 [Benson, "Consideration"]. See also Benson's just-published book, which takes up many of these same arguments and ties them with a Rawlsian-inspired theory of contractual justice: Peter Benson, Justice in Transactions: A Theory of Contract Law (Cambridge, Mass: Harvard University Press, 2019).

Benson, "Consideration," ibid at 278.

Weinrib, supra note 4 at 138, n 30, citing Benson, "Contract Law," supra note 4.

Such an explanation appears to be all the more warranted given that it is the agreement now concluded by means of a sealed instrument, rather than the consideration-based exchange, which corresponds to the common law's oldest form of contractual cause of action: see DJ Ibbetson, A Historical Introduction to the Law of Obligations (Oxford: Oxford University Press, 1999) at 21. Contrast however Simpson's view that debt, not covenant, is "the earliest writ of a contractual nature to be regularly issued": AWB Simpson, A History of the Common Law of Contract: The Rise of the Action of Assumpsit (Oxford: Clarendon Press, 1987) at 53. 
The second, perhaps more fundamental problem with the approach that both Benson and Weinrib take towards sealed instruments pertains by contrast to the fact that neither author actually attempts to explain why the common law enforces even gratuitous promises made in this form. The foregoing explanation is simply limited to telling us that the common law has made a decision to enforce sealed promises at some point in its history, without offering any further guidance as to the higher-order principles (beyond mere utility) on which this decision might have been anchored. Even accepting that the seal amounts to a mere policy choice does not, of course, foreclose the possibility of identifying at least some underlying principle on which the common law has chosen to elaborate in this way.

It is in this last respect that Weinrib's and Benson's accounts of the seal differ from that of Alan Brudner. Like the former authors, Brudner provides an alternative reading of the seal that distinguishes it from consideration-based contracts. However, he also attempts to explain the operation of sealed instruments, rather than simply discounting them as irrelevant to the domain of contract entirely. As Brudner argues:

In fact, gratuitous promises under seal are enforced not as executory contracts but as executed gifts. A gift does not pass title to the donee until delivered, but the delivery of a sealed deed of gift counts as a symbolic delivery of the object. In the same way, a promise signed, sealed, and delivered transfers possessory title to the donee, and the court enforces that title. Thus, the seal is not an alternative to consideration in triggering the enforcement of a promise; rather it is something that (along with delivery) transforms a promise into an executed transfer - a conveyance. By contrast, the element required for the enforceability of a promise as promise is consideration. So, inasmuch as the seal belongs to the deed of gift whereas consideration belongs to contract, we cannot surmise anything about the point of consideration - even nominal consideration from the function of the seal. ${ }^{32}$

As the last sentence of the above excerpt suggests, Brudner's discussion of the seal is primarily aimed at distinguishing its effects from those of consideration as exchange. His main objective, like that of Benson and Weinrib, is thus to rebut Fuller's account of consideration as one "good reason for enforcing a promise" among many others, and to establish the requirement of consideration as exchange as a central element of contract. ${ }^{33}$ Nonetheless, he goes further than both Weinrib and Benson by actually proposing an explanation for the seal's effects that references another established legal category: the executed gift. Brudner's chief contribution in this respect is through his proposed analogy between the seal and the notion of symbolic delivery, which the common law admits as a way of completing gifts under particular circumstances.

This argument solves the most obvious gap in Benson's and Weinrib's analyses, but is also subject to at least two important limitations of its own. First, Brudner's proposed connection between agreements under seal and executed gifts is likely not a natural one for lawyers trained in the common law tradition, most of whom would likely classify promises under seal within the domain of contract and executed gifts in property law. ${ }^{34}$ This tendency

Brudner \& Nadler, supra note 6 at 199 [emphasis in original].

Ibid at 198 .

For treatment of the promise under seal as a concept belonging to the law of contract, see e.g. Lon L Fuller, Basic Contract Law (St Paul, Minn: West Publishing, 1947) at 313 [Fuller, Basic Contract]; HG Beale, ed, Chitty on Contracts, 29th ed (London, UK: Sweet \& Maxwell, 2004) vol 1 at paras 1-075 to 1-095; Waddams, supra note 9 at paras 168-74; GHL Fridman, The Law of Contract in Canada, 6th ed (Toronto: Carswell, 2011) at 116-18. For treatment of the executed gift as a property law concept, see Ray Andrews Brown, The Law of Personal Property, 2nd ed (Chicago: Callaghan \& Company, 1955) 
is only reinforced by the important differences that exist between sealed instruments, which can be used to create all sorts of legal entitlements including apparent obligations to render future performance, and the executed gift, which is largely limited to the immediate transfer of particularized - and usually tangible — property. Second, and perhaps most importantly, Brudner's account of sealed instruments only offers a partial explanation for its effects by presenting the use of the instrument as a substitute for the physical delivery of property. However, Brudner does not really explain why the latter is normally required to effect a unilateral transfer by gift in the first place, much less why a formalized document can serve as a viable substitute. ${ }^{35}$

What we can conclude, then, is that Brudner's analogy between sealed instruments and symbolic delivery remains broadly consistent with the approach taken by both Benson and Weinrib, even as it takes their conclusions with respect to these devices one step further. For Brudner, as for these other authors, there appears to be only one solution to the dilemma posed by the sealed instrument to contract as exchange: to distinguish the agreement concluded in this way from the exchange-based contract - and to further cast it out from the domain of "contract," as they define it, entirely. Brudner's additional contribution is thus to propose an analogy between the seal and another established legal category that is generally understood to be distinct from the contract - that is, the executed gift. While not without its own limitations, this argument is largely consistent with the manner in which I have proposed that sealed instruments might be reconciled with promissory theories of contract above, and in this sense provides us with a starting point for further reflection on this formality irrespective of which understanding of contract we ultimately adopt for ourselves.

\section{UNILATERAL TRANSFER AND THE EXECUTED GIFT}

In Part II of this article, I argued that while both promissory and exchange-based theories of contract appear to discount the theoretical relevance of sealed instruments to contract law proper, they leave open an alternative possibility by which we might seek to explain the effects of these devices. This possibility corresponds to Brudner's suggestion, according to which sealed instruments might be better explained not by reference to the considerationbased contract, or even to promises generally, but rather by analogy to the executed gift as a means of completing an immediate, unilateral transfer of property.

In this part of the article, I will begin to elaborate upon this analogy by offering an account of the executed gift as the paradigmatic case of unilateral transfer recognized within the common law tradition. As I will argue, the enforcement of a gift in the aforementioned terms can be understood within a relatively broad, two-part conception of contractual transfers. Specifically, an agreement or promise to perform some act in the future can be distinguished from an agreement - typically termed a "conveyance" in common law sources — by which one party actually tenders the performance so promised by transferring property, and through which the other accepts that performance in accordance with the original promissory

at chs 7-8; Bruce Ziff, Principles of Property Law, 5th ed (Toronto: Carswell, 2010) at 156-66; Mary Jane Mossman \& Philip Girard, Property Law: Cases and Commentary, 3rd ed (Toronto: Emond Montgomery, 2014) at 430.

35 This omission is no doubt intentional, as Brudner's account of delivery, like his account of the seal, is merely ancillary to, and ultimately meant to support the centrality of, the requirement of consideration as exchange: see Brudner \& Nadler, supra note 6 at 127. 
undertaking. ${ }^{36}$ The executed gift, as an agreement concluded simultaneously with its performance by means of delivery, falls within the second category. It thus amounts to a "contract," understood in the civilian sense of an agreement or bilateral juridical act requiring offer and acceptance, albeit one that arises either in the absence of an enforceable promise, or else in the absence of an earlier agreement altogether. ${ }^{37}$

My argument will proceed in two parts. First, I will examine the agreement that I suggest lies at the heart of the executed gift, and which is embodied in the twin requirements that the donor intends to transfer ownership of the gift property, and that the donee intends to accept it. Second, I will tie these consensual requirements to the formal requirement of delivery, which I will suggest serves both as the means through which the gift agreement is concluded, and the manner in which that agreement is performed at the very same moment it comes into existence. In this way, offer, acceptance, and performance of the transfer of gift property can be said to all occur at once, such that the donor, having willingly and completely performed the agreement at the moment of its conclusion, can no longer hold any claim over the gift property against the donee.

\section{A. Agreement And GifT}

Since the executed gift is generally understood as a conveyance within the common law tradition, it is accordingly classified within the domain of property law, rather than contract. ${ }^{38}$ This conclusion presents undeniable appeal. If a gift serves to transfer property, and is perhaps enforceable only as a completed transfer of property (as is typically understood in common law jurisdictions), then it seems to follow that the very essence of the gift lies in its property-transferring effects: to borrow the words used by certain authors, it is a "simultaneous transaction" or a "gratuitous act of transference," not a "contract." 39 That said, a primarily proprietary view of the executed gift also presents at least one important conceptual problem that remains largely unaddressed within the common law literature. Namely, if the executed gift is enforceable as a completed transfer of property, then focusing on the effects of the transaction offers no explanation as to why the gift allows for such a transfer to occur in the first place. ${ }^{40}$ Notions such as "simultaneous transaction" and

36 To quote from Kant, supra note 7 at 60-61 [emphasis omitted]:

If I conclude a contract about a thing that I want to acquire, for example, a horse, and at the same time put it in my stable or otherwise in my physical possession, it is then mine (vi pacti re initi), and my right is a right to the thing... Now if a contract does not include delivery at the same time (as pactum re initium), so that some time elapses between its being concluded and my taking possession of what I am acquiring, during this time I cannot gain possession without exercising a separate act to establish that right, namely a possessory act (actum possessorium), which constitutes a separate contract.

37 The Kantian view is explicit that such an agreement to transfer property rights need not arise following an earlier promissory contract: see ibid. It is in this sense broadly consistent with both the approach of modern German law and the Roman law idea of a "real contract": see Inst 3.14 (edited by John Baron Moyle) ("[r]eal contracts, or contracts concluded by delivery, are exemplified by loan for consumption, that is to say, loan of such things as are estimated by weight, number, or measure, for instance, wine, oil, corn, coined money, copper, silver, or gold: things in which we transfer our property on condition that the receiver shall transfer to us, at a future time, not the same things, but other things of the same kind and quality").

38 See supra note 34 and accompanying text.

39 Smith, supra note 2 at 63; Martin Hogg, Promises and Contract Law: Comparative Perspectives (Cambridge, UK: Cambridge University Press, 2011) at 47.

40 As Helge Dedek has argued, a similar problem can be taken to have affected traditional accounts of the transfer theory of contract, which start from the presumption that contracts are valid by analogy to a completed transfer of property, but use the notion of contract to justify the occurrence of that transfer in the first place; as the argument goes, a truly effective transfer (such as a derivative acquisition of property from a previous owner) should be impossible under this version of the theory, since in the 
"gratuitous act of transference" simply assume that the gift is enforceable as a transfer of property, without going any further. ${ }^{41}$

By contrast, any suggestion that the executed gift amounts to a separate, self-contained and immediately performed agreement - and particularly, one that need not be preceded by any formal act of promising - requires that we establish the existence of such an agreement in the first place. On this view, the conclusion of the gift agreement would need to occur by way of an offer and acceptance, mediated through the simultaneous delivery, and thus transfer, of the gift property. It is the confluence of all three, with delivery serving as performance of the underlying agreement, that accordingly provides the basis for the donee's acquisition of ownership directly from the donor, rather than as a unilateral acquisition of abandoned property. ${ }^{42}$

As it happens, this broadly contractual conception of the executed gift not only avoids the conceptual difficulties that I have just referenced, but also at least arguably offers the best explanation for the manner in which this transaction actually operates at common law. There are at least three aspects of the executed gift that point to such a conclusion in particular, each corresponding in turn to one of the aforementioned elements required to conclude an executed gift at common law - that is, to the animus donandi or intention to give, to acceptance, and to the requirement of delivery itself. ${ }^{43}$ If we begin with the intention to give - the animus donandi - this requirement appears on its face to mandate that we understand the executed gift as a transaction that is intended by the donor. This requirement, however, also does more than serve as an essential condition of the gift's validity: it is effectively the only means by which the gratuitous transfer of ownership that the gift effects can be determined to have taken place at all. This is because the same act that allows the gift to be performed — the requirement of delivery — is also associated with a number of alternative arrangements, including certain common law transactions that do not give rise to the same types of legal consequences.

absence of an agreement preceding the transfer the transferor has no choice but to unilaterally abandon the property in question, which the transferee must then unilaterally acquire in an unowned state: see Helge Dedek, "A Particle of Freedom: Natural Law Thought and the Kantian Theory of Transfer by Contract" (2012) 25:2 Can JL \& Jur 313 at 337. For an example of such a theory, see most notably Hugo Grotius, De Jure Belli Ac Pacis Libri Tres, translated by Francis W Kelsey (Oxford: Clarendon Press, 1925) vol 2, book 2 at 329. While Dedek is primarily concerned with this problem in relation to the enforcement of promises by analogy to the transfer of property, the same problem arises in relation to the unilateral transfer of property by a donor to a donee, a point which Hegel appears to recognize when he presents the gift as the product of a common will: Hegel's Philosophy of Right, translated by TM Knox (London, UK: Oxford University Press, 1967) at para 76.

41 On a more basic level, we can also add that if the gift corresponds to a completed transfer of ownership over gift property, the donor must have at a minimum chosen to part with the gift property, and that the donee must just as importantly have accepted that transfer, since no person can be compelled to accept even a benefit against her will: see Saint John Tug Boat Co Ltd v Irving Refining Ltd, [1964] SCR 614 at 622 [Saint John], citing Falcke v Scottish Imperial Insurance Company, [1886] 34 Ch D (CA) 234 at 248 , Bowen LJ.

42 As Kant puts it, "[t]ransfer by contract of what is mine takes place in accordance with the law of continuity (lex continui), that is, possession of the object is not interrupted for a moment during this act; for otherwise I would acquire, in this condition, an object as something that has no possessor (res vacua), hence would acquire it originally, and this contradicts the concept of contract": Kant, supra note 7 at 59. This understanding of the gift (though not of its relationship with promissory agreements) is also broadly compatible with Hegel's account of the gift, from which I have drawn the idea of property serving to "mediate" the agreement: see Hegel's Philosophy of Right, supra note 40 at paras 74, 76.

43 These three elements are generally admitted as requirements for a valid gift inter vivos in Canada as elsewhere, at least when the gift is not completed by means of a deed: see Ziff, supra note 34 at 157; Mossman \& Girard, supra note 34 at 431. 
Such is the case, for example, where particular property is delivered not with the intention to complete a gift, but rather with the intention to create a bailment. ${ }^{44}$ Like the executed gift, a bailment is also enforceable without consideration, provided that the bailor has actually delivered the bailed thing to the bailee at the moment their agreement is concluded. ${ }^{45}$ It is also intrinsically tied to the requirement of delivery — so much so, in fact, that the bailee will generally be liable in that capacity only while she has physical control of the thing in question, even if the bailment arises in the context of a broader contractual relationship. ${ }^{46}$ And yet, while the rights conferred on a bailee upon delivery may be more or less exhaustive, a bailment cannot confer a full right of ownership over the thing at issue. Such an arrangement would cease to be a bailment, and instead become an executed gift. ${ }^{47}$

What accounts for the difference between these two transactions - and thus allows us to determine whether a particular thing has been delivered pursuant to a gift or a bailment? The common law's answer to this question must almost certainly be rooted in the intention of the transferor - which is to say, in the existence of an animus donandi or some alternative intention. Like the executed gift, the underlying bailment agreement appears to become enforceable on account of its performance through the immediate and simultaneous delivery of the bailed property. The only difference with the executed gift lies at the level of the underlying intention: where the delivering party intends to bail a thing, and the receiving party accepts delivery of the bailed property on that basis, or at least on a basis that is not contrary to the nature of bailment, the common law gives effect to that intent and recognizes a validly constituted bailment. ${ }^{48}$ Where the delivering party instead intends to give the thing, or to deliver it for some other valid purpose, the common law will not recognize a bailment, but rather a gift or some other form of unilateral transfer. ${ }^{49}$ The underlying agreement, in the form of the transferor's intention as accepted by the transferee, is the only proper basis on which to account for the difference between these two types of transaction.

At the same time, and as the case law itself generally recognizes, the act of delivery in the sense of physically handing over a thing — presents an inherent element of ambiguity. It cannot be taken as sufficient on its own to constitute a gift or, for that matter, a bailment, or any other legally recognizable transaction whatsoever. ${ }^{50}$ What we can conclude from the manner in which the common law generally approaches the animus donandi, then, is that the gift requires at a minimum an expression of intention — objectively understood — which allows the donee, and eventually a court, to conclude that the donor wanted the gift property to pass to the donee, rather than to effect some other result. While delivery may suffice in most cases to evince such an intention, particularly when viewed in the broader context of the relationship between the parties, such will not always be the case. There is here a strong

$44 \quad$ It should be noted that this category of transaction is largely unique to the common law, and can be understood to encompass a number of distinct classes of contract (usually real contracts) recognized by both Roman law and modern civil law: see generally the classic account of bailment in William Jones, An Essay on The Law of Bailments (Dublin: Graisberry and Campbell, 1790). See also the discussion in Reinhard Zimmermann, The Law of Obligations: Roman Foundations of the Civilian Tradition (Cape Town: Juta \& Co, 1990) at 203-205.

$45 \quad$ Wheatley $v$ Low (1791), 79 ER 578 (KB); Whitehead v Greetham (1825), 130 ER 385 at 387 (Exch); Shillibeer $v$ Glyn (1836), 150 ER 704 (Exch of Pleas).

See e.g. Burridge $v$ Hardy, 2018 ONSC 202 at para 107.

Mercer v Craven Grain Storage Ltd, [1994] CLC 328 (HL).

Appleton v Ritchie Taxi, [1942] OR 446 (CA).

This same underlying intention is also what distinguishes the bailment from property delivered in the context of a sale: see The South Australian Insurance Co v Randell, [1869] UKPC 71.

See e.g. Re Cole (1963), [1964] 1 Ch 175 (CA), where donor and donee were living together at the time of the purported gift and thus already had common possession of the furniture at issue. 
parallel between this element of a gift and the requirement of an offer as it pertains to contracts, which is similarly understood to require an objective demonstration of intention by both promisor and promisee to be legally bound to the essential terms of a particular transaction. ${ }^{51}$

Turning to the second requirement - acceptance - it too can be taken to imply the existence of intention: this time, on the part of the donee. We might accordingly be left to imply that the executed gift corresponds at least formally to a bilateral arrangement or agreement similar to the common law contract. ${ }^{52}$ The question that arises here is whether this requirement of acceptance can further be taken to correspond to the existence of a proper consensus ad idem between the parties, in which the donor's intention to give is accepted by the donee and their "wills" can thus be taken to meet, rather than to the mere physical acceptance of the gift property.

As with the broader role played by the intention to give, it appears that the requirement of acceptance as it pertains to executed gifts at common law can indeed be taken to extend beyond the mere physical acceptance of the thing at issue. While the common law admittedly adopts a somewhat different approach towards the gift, which can be presumed to have been accepted by the donee, and the consideration-based contract, which is generally considered incapable of tacit acceptance, these divergent attitudes can be accounted for on the basis of the aforementioned objective theory of intention. ${ }^{53}$ For while it remains settled law that the promisee must normally communicate her acceptance to the promisor to create a binding contract, the exceptions that allow silence to be taken as acceptance are also well-established. Such will be the case, for instance, where the offer was made on terms that explicitly allow for acceptance in such a way, or where the terms of the offer and the previous conduct of the parties make it reasonable for the promisor to presume acceptance in the absence of an express communication to the contrary. ${ }^{54}$ If we turn to the case of the gift, we find that the reasoning that supports silence as acceptance in the foregoing cases is equally applicable, if not more so. The donor is, after all, giving something to the donee immediately and for nothing. There is usually little that the parties can or would want to negotiate with respect to such a transaction, as the donee can be reasonably expected to accept a benefit that is conferred upon her without a corresponding obligation to the donor.

Moreover, that the donee's acceptance amounts to a requirement that at least appears to impose a proper consensus ad idem with the donor, rather than a mere physical acceptance of the gift property, can be further inferred from those cases where the meaning of physical delivery is ambiguous, or where physical delivery to the donee does not occur at all. In the

$51 \quad$ See Smith v Hughes (1871), LR 6 QB 597 at 607, Blackburn J (“[i]f, whatever a man's real intention may be, he so conducts himself that a reasonable man would believe that he was assenting to the terms proposed by the other party, and that other party upon that belief enters into the contract with him, the man thus conducting himself would be equally bound as if he had intended to agree to the other party's terms"). See also Staimen Steel Ltd v Commercial \& Home Builders Ltd (1976), 13 OR (2d) 315 (Sup $\mathrm{Ct}$ ).

52 But see Martin A Hogg, "Promise and Donation in Louisiana and Comparative Law" (2011) 26 Tul Eur \& Civ LF 171 at 172 ("protecting against unconsidered giving need not necessitate dressing up a unilateral act in bilateral clothing, and giving a donee a right of rejection is just as suited to preventing unwanted donations as is requiring the donee to accept").

53 For the default rules applicable to each category of transaction, see Standing v Bowring (1885), $31 \mathrm{Ch}$ D 282 at 286 (CA); Felthouse $v$ Bindley, [1862] EWHC CP J35.

$54 \quad$ See e.g. Carlill v Carbolic Smoke Ball Company (1892), [1893] EWCA Civ 1; Saint John, supra note 41. 
first set of cases, the presumed acceptance of the donee will, of course, mean that she may validly accept the gift while under the subjective impression that the donor intends to lend it, rather than transfer it completely. Nonetheless, the essential condition here remains one of objective intent: the donee must accordingly refrain from acting in a way — and thus expressing an intention - that is contrary to her acceptance of the gift as a full and immediate transfer. ${ }^{55}$

The second set of cases, meanwhile, can be taken to include not just those cases in which the gift is completed by means of the delivery of something else that serves to represent the gift property - that is, by means of symbolic delivery, a possibility that I will examine in greater detail below — but also the possibility that the gift might be concluded by delivery not to the donee personally, but rather to a third party. The essential requirement here is again one of intention: for delivery to be effective where it is made to a third party, the third party must have accepted the transfer in the name of the donee and for her benefit, just as the donee must accept the symbolic representation as a stand-in for the gift property to conclude a gift by means of symbolic delivery. ${ }^{56}$ Since the gift is nonetheless taken to have been accepted by the donee in either case, we can infer here that this requirement presents a more properly normative, as opposed to purely physical, dimension: the donee is now the owner of the gift property, even though she has not yet taken physical possession of it.

What we can conclude from the foregoing, then, is that the common law approach to the acceptance of a gift again appears to be in keeping with its broader "objective" approach to contract formation, in that acceptance of the physical gift property will generally imply the acceptance of such an intention, though this appears to remain only a presumption that can be rebutted on the basis of the broader context. On this reading, the donee thus remains free to reject the gift despite physical acceptance, provided that she expresses such an intention in an objective manner at the point in which physical acceptance is made.

This conclusion as to the requirement of acceptance brings us to the third and final aspect of the executed gift that supports its understanding as an agreement first, and as a transfer of property second. It corresponds to the possibility that a gift might be concluded in a manner that remains subject to conditions similar to the contractual condition precedent and condition subsequent — which is to say, by either suspending its effects until a later condition is fulfilled, or else requiring reversion of the gift property to the donor upon its occurrence. ${ }^{57}$ This very possibility seems to discount any reading of the gift simply as a completed transfer of property, since the enforcement of the conditions appears to depend upon the existence of an underlying agreement that continues to dictate the terms of the donee's resulting entitlement, even beyond the point of delivery. To understand the way in which these conditions operate, however - and for that matter, the way they can be

Dewar v Dewar, [1975] 1 WLR 1532 (Ch) at 1538-39.

Moore v Darton (1851), 64 ER 938 at 939. See also Walker v Foster (1900), 30 SCR 299 at 302 [Walker] (suggesting that this rule does not require the third party to be legally empowered to accept as agent or trustee for the gift to be validly made through such third-party delivery).

57 I will examine two such cases of conditional gift below, namely, the donatio mortis causa and the gift made in contemplation of marriage. The common law does not, however, recognize anything like the general right to revoke a gift for ingratitude that is recognized, for example, at art $955 \mathrm{C}$ civ. The historical basis for this right in those jurisdictions that have followed the French Civil Code is discussed in John P Dawson, Gifts and Promises: Continental and American Law Compared (New Haven: Yale University Press, 1980) at 45-48. 
reconciled with the idea of an executed gift as a completed transfer of property - we must turn our attention to the role that is served by delivery itself.

\section{B. Performance ANd Delivery}

Each of the three features of the executed gift examined above points to the primacy of the underlying agreement over the resulting transfer of property. Each also tends to suggest that the executed gift constitutes a particular kind of self-contained agreement that is both concluded and performed at the point of delivery. As I have suggested, it is the donor's intention at the precise moment in which delivery occurs that determines the legal consequences attached to the act of delivery itself. That act would be entirely devoid of legal consequence in the absence of donative intention or the intention to complete some other type of transfer.

This conclusion provides us with a good starting point to understand the operation of the executed gift at common law. However, it is insufficient to account for the precise reason why delivery is required to effect a transfer of ownership by means of gift, and thus perform the underlying gift agreement. More fundamentally still, it remains to be seen why the common law requires an act of performance - be it in the form of physical delivery or otherwise - in the first place, rather than simply recognizing a completed transfer of property rights on the basis of the parties' intention alone. ${ }^{58}$ These are ancient requirements, and it is not always apparent what the justification for their continued imposition might be. ${ }^{59}$

The answer to these questions, I want to suggest, lies in understanding both the immediacy of the effects that the gift agreement is intended to generate between the parties, as well as the conditions that must generally be met in order for these effects to be achieved. The first part of this explanation is thus relatively straightforward: since the gift agreement pertains to an immediate transfer of ownership from the donor to the donee, and is in this sense distinct from any promise that may have preceded it, it follows that the donee's intention to actually accept the gift property must be determined on the same basis and at the same time as the donor's expressed intention to give — that is, at a particular moment that happens to correspond to the donor's delivery of the gift property as performance of the gift agreement. ${ }^{60}$ It is at this moment - not before or after - that the rights and duties of the parties are fully determined, such that the donee must choose to either accept or refuse the gift property on its face, as a manifestation of the donor's underlying intention.

$58 \quad$ As the position of French law on the issue makes clear, it is at least conceivable that such a transfer might take place by agreement alone, without the donor needing to complete any additional formality: see art $1138 \mathrm{CcF}$; art $1196 \mathrm{C}$ civ. See also Grotius, supra note 40 at 261 ("[t]he requirement that delivery of the property take place arises from municipal law").

59 This difficulty is evident even from the English Court of Appeal decision in Cochrane v Moore (1890), 25 QBD 57 at 65-66 (CA), which probably remains the leading authority on the requirement of delivery as it pertains to gifts in much of the common law world. While both the majority and the concurring judgment in that case affirm the basic requirement of delivery, their arguments remain largely if not entirely confined to a historical analysis of existing precedent and do not offer any further justifications for the rule itself.

60 As Lord Escher put it in Cochrane v Moore, a gift is "a transaction begun and completed at once. It is a transaction consisting of two contemporaneous acts, which at once complete the transaction, so that there is nothing more to be done by either party. The act done by the one is that he gives; the act done by the other is that he accepts. These contemporaneous acts being done, neither party has anything more to do" (ibid at 75-76). 
Stated differently, we can affirm that delivery, or some alternative act of performance, is required simply because of the immediate nature of the gift agreement, by which there must exist some moment in which offer, acceptance, and performance can occur simultaneously. Since delivery puts the donee in physical possession of the gift property, it serves as a practical and ascertainable moment where these three elements can be taken to have been met, particularly as it is the likely point in which the donee will choose to accept or reject the gift property, and the performance of the underlying agreement alongside it. Once the donee has accepted both the intention to give and the performance of the gift, enforcement of the agreement merely reflects the new legal status quo: the donor is no longer the owner of the delivered thing, which is instead owned by the donee.

The question of whether delivery will serve to effectively mark performance of the gift agreement in this way, and thus transfer ownership of the gift property to the donee, is fundamentally one of control: the act of delivery must entirely divest the donor of control over the gift property for the gift to be effectively performed. ${ }^{61}$ While this requirement may not entirely foreclose the possibility of concluding a gift on a conditional basis, we can expect that it will severely constrain the types of conditions that can be validly attached to one. In particular, it is apparent that such a condition should not be of the sort that allows the donor to effectively withhold the transfer at her discretion - which would, in effect, allow her to withhold performance of the underlying gift agreement.

Each of the two major cases of conditional gift recognized by the common law appears to conform with these expectations in its own way. These are, namely, the donatio mortis causa - the non-testamentary gift made in anticipation of death — and the gift made in contemplation of marriage, respectively. ${ }^{62}$ In the first case, all of the essential elements of the gift, in the form of an intention to give, acceptance, and delivery, must generally be met prior to death, even as the gift itself will only become effective as a transfer of ownership over the gift property if the donor then dies as a result of the same peril that led her to make the gift in the first place. ${ }^{63}$ In the second, the gift is instead taken to be fully performed from the outset, even as the gift may later become void if the anticipated marriage never occurs, or else subsequently fails. ${ }^{64}$

Drawing an analogy with the law of contracts, it is possible here to view the former type of conditional gift in similar terms to the contract made subject to a condition precedent that is, a condition that suspends the enforcement of the contractual obligation, if not the

61 This result is not achieved where the donor has conserved the ability to revoke the gift at will by means of a condition or by delivering it to a third party acting as her agent or trustee: see e.g. Walker, supra note 56 at 301 .

62 A third and potentially more generalizable class of conditional gift can perhaps be deduced from the rules in equity, including those pertaining specifically to the resulting trust: see Robert Chambers, "Conditional Gifts" in Norman Palmer \& Ewan McKendrick, eds, Interests in Goods, 2nd ed (London, UK: LLP, 1998) 429 at 433 . While it is not my intention to deal with the nature of equitable interests here, I note that the question of whether a resulting trust has arisen can generally be tied to whether the donor truly (i.e. subjectively) intended to confer full control of the gift property to the donee in the first place, and can in this sense be more closely analogized (though perhaps not fully equated) to a claim in unjust enrichment than to the two classes of properly conditional gift discussed in this article: see Nishi $v$ Rascal Trucking Ltd, 2013 SCC 33.

63 McDonald v McDonald (1903), 33 SCR 145 at 161; Thompson v Mechan, [1958] OR 357 (CA). But see Cain $v$ Moon, [1896] 2 QBD 283 (suggesting that the donatio mortis causa is one in which the gift property vests immediately in the donee but reverts back to the donor if death does not occur).

64 McManus v McCarthy, 2007 ABQB 783. But see Schilthuis v Arnold, 1996 CanLII 463 (Ont CA) (suggesting that a gift - in this case made by deed - can be made subject to a condition precedent attached to the solemnization of a marriage as well). 
creation of the obligation itself. ${ }^{65}$ The latter, by contrast, can be taken instead as being made subject to a condition subsequent, which retroactively brings an end to all or part of the underlying agreement - in this case, the part of the agreement that pertains to the transfer of property rights. ${ }^{66}$ But there is an important difference in both cases with the conditional contract: whereas the condition that attaches to contractual obligation - whether in the nature of a condition precedent or condition subsequent - remains tied to whether performance must be rendered on the agreement that the parties have concluded, here the condition attaches to the effects of the performance that the donor has already rendered. ${ }^{67}$ In the case of a donatio mortis causa, the only question that thus remains is whether the transfer will occur on its own, without any further act being required from the donor; she has ceded both physical and legal control since the condition to be fulfilled — the donor's death — is, at least legally, entirely outside her control. ${ }^{68}$ In the case of a gift made in contemplation of marriage, the question is instead whether the agreement will be retroactively rescinded, and the transfer, which has already occurred, made subject to reversion. The condition that attaches to the rescission, however, is also outside the donor's control — whether it pertains to the celebration of the promised marriage, or else to the spouses remaining together once the marriage is solemnized.

The foregoing accounts for why a gift must be immediately performed as a general matter, and thus for why there must be a precise moment in which offer, acceptance, and performance are made or rendered simultaneously. However, it still does not definitively establish why delivery should be chosen to fill this role. We might be tempted instead to simply select the moment in which the parties reached an agreement - that is, when the meeting of the minds occurred - as the moment in which ownership passes from the donor to the donee, or else to leave the choice of this moment to the parties themselves. The gift agreement would accordingly be "performed" automatically at the very moment in which it is concluded, or else at some alternative point that the parties have selected. ${ }^{69}$

To fully answer the question of why delivery or some other equivalent act of performance is required to complete a gift at common law, there is one final point that must be considered, and which pertains more narrowly to the nature of the right being tendered to the donee in performance of the gift. That right - a right of ownership over the gift property - amounts at least theoretically to a complete property right and not to a mere contractual right to demand performance from the donor at some later time. It is a right in rem that is potentially enforceable against anyone who might interact with that thing. ${ }^{70}$ As a number of authors have

65 See Turney $v$ Zhilka, [1959] SCR 578 at 583-84. The conditions attaching to testamentary dispositions in particular have often been framed in precisely these terms: see e.g. Woods Estate $v$ Woods (2005), 260 DLR (4th) 341 (Ont CA) [Woods].

$66 \quad$ Woods, ibid at para 14.

${ }_{67}$ Wilson v Clarke Simpkins Ltd (1961), 30 DLR (2d) 745 at 748 (BCCA); Graham v Wagman (1978), 21 OR (2d) 1 .

68 To the extent that the donor commits suicide after the fact, we can query whether the gift should remain valid under the general rules of gift law (the donor having intended to convey the gift property outright while she was still alive). But see Re Fanning (1922), 53 OLR 86 (SC) ("[i]t cannot be supported as donatio mortis causa, first because it is essential to such a gift that it should be made under the apprehension of death from existing disease or other impending peril, and, secondly, it is plain that the gift was in fact in contemplation of suicide, and this invalidates the whole proceeding"). See also Agnew $\checkmark$ Belfast Banking Co, [1896] 2 IR 204.

69 This approach would again generally conform to that of French law: see most notably art $938 \mathrm{C} \mathrm{Civ.}$ I am here largely adopting the understanding of the in rem right put forward in Wesley Newcomb Hohfeld, "Fundamental Legal Conceptions as Applied in Judicial Reasoning" (1916-1917) 26:8 Yale LJ 710 at 718 . 
remarked, such a class of right presents an additional level of difficulty insofar as the third parties in question have not consented to, and may in fact lack knowledge of, the right's existence. ${ }^{71}$ Moreover, and regardless of the legitimacy of the property right itself, there remains here an important practical issue insofar as its transfer might be effected without at least the possibility of third party knowledge: such third parties would be bound to respect the transfer, even if they did not - and perhaps could not - know of its occurrence. ${ }^{72}$

Viewed from this perspective, the requirement of delivery as it pertains to gifts can thus be understood to not only serve as the means by which offer and acceptance are exchanged, but also the means by which the performance of the underlying agreement between the parties can be properly externalized and made enforceable against third parties. By giving the donee physical possession of the gift property, delivery at least provides notice to such parties that a transfer of rights may have occurred, and in so doing allows for what is an otherwise private transaction to be set up against anyone who may subsequently claim an interest in it. ${ }^{73}$

In other words, the requirement of delivery can be explained — and justified - by reference to its role as marking not only the performance of an agreement to transfer rights, but also providing notice to third parties of the change in ownership. There are, of course, other ways by which such a result can be achieved, and the common law is not entirely closed off to them as a general matter. I have already mentioned the possibility of symbolic or constructive delivery above, corresponding to delivery not of the gift property itself, but of something else that can be understood to represent it. ${ }^{74}$ The general rule here appears to allow for alternative modes of delivery to be admitted where the nature of the gift property itself makes physical delivery impractical, though not necessarily impossible. ${ }^{75}$ These alternatives are particularly relevant in the case of two types of things that have thus far been largely overlooked in my analysis so far: in the case of rights in real property, which are incapable of physical delivery by virtue of being rights to land or space, and choses in action, which are by their very name incapable of physical possession altogether except when represented by something else, usually in the form of a written instrument. ${ }^{76}$

71 For Kant, for example, the very notion of an acquired right appears to present an important challenge since these rights are arbitrarily assigned to individuals rather than innate to them; there is accordingly no guarantee that any given individual will, or will not, acquire a particular thing as her own: see Kant, supra note 7 at 44-45. As others have also remarked, this problem is particularly acute in the case of in rem rights, which are at least theoretically binding against an indeterminate class of persons - that is, against anyone who might come into possession of a particular thing, regardless of whether they have consented to or have knowledge of the right's claimed existence: see e.g. B Sharon Byrd \& Joachim Hruschka, Kant's Doctrine of Right: A Commentary (Cambridge, UK: Cambridge University Press, 2010) at 121.

72 This difficulty appears to be at least implicitly recognized even by those authors who generally discount the relevance of delivery to the transfer of property rights: see e.g. Peter Benson, "Contract as a Transfer of Ownership" (2007) 48:5 Wm \& Mary L Rev 1673 at 1697, 1707. As I have argued elsewhere, Benson's position in this respect echoes that of French law, which likewise requires delivery or registration of a transfer as a condition of third-party enforcement: see art $1198 \mathrm{C}$ civ. See also arts 1454, 2941 CCQ.

73 The idea here is neatly summarized by a French maxim that had been codified in art $2279 \mathrm{CcF}$ ("En fait de meubles, la possession vaut titre" — that is, "with regards to moveable property, possession counts as title").

74 This was the basis on which Brudner in particular analogized the effects of the seal to that of delivery in the case of gifts: see Brudner \& Nadler, supra note 6 and accompanying text.

75 Brown, supra note 34 at 101 . This reading remains broadly consistent with the general view that the law will not complete an incomplete gift: see Milroy $v$ Lord, [1862] EWHC Ch J78.

76 In respect of the latter, see e.g. Dickson $v$ Chamberland (1927), 22 Alta LR 393 at $407-408$ (SC (AD)). 


\section{UNILATERAL TRANSFER AND SEALED INSTRUMENTS}

In Part II of this article, I suggested that both promissory and exchange-based theories of contract point to a possible explanation for the effects of sealed instruments rooted not in strictly contractual principles, but by analogy to a completed transfer of property rights. I then proceeded in Part III to examine what I presented as the paradigmatic form of unilateral transfer recognized by the common law — that is, the executed gift. As I argued, this class of transaction can be understood as a form of immediately performed agreement in which offer and acceptance occur simultaneously with, and are communicated through, the act of delivery, which also serves to render that performance.

In this fourth and final part of this article, I will attempt to construct a more general theory of unilateral transfer by conceptualizing the effects of an agreement concluded by means of a sealed instrument in precisely the same way as the executed gift described above. As I will argue, such an agreement can also be understood to correspond to one in which offer, acceptance, and performance occur simultaneously upon the delivery of a particular thing. Following the general division of Part III, I will begin by outlining the particular features of the agreement concluded by way of a sealed instrument, with a particular focus on how it amounts to a self-contained and simultaneously performed agreement that serves to transfer rights in a manner that is entirely separate from any previously concluded promise to that effect. Having done so, I will then focus more narrowly on how the use of a sealed instrument might serve to render performance of that agreement. I will suggest that this arrangement allows it to serve not only as a means of transferring certain types of property that are normally not capable of physical delivery, but also create future obligations namely, by transferring an in personam right to demand future performance from a particular person - in a manner that is largely analogous to the consideration-based contract.

\section{A. Agreement And SEALED InSTRuments}

Unlike the case of the gift, the status of the sealed instrument as a means of concluding an agreement — in the sense of a consensus ad idem — can be largely taken for granted for the purpose of this article. Indeed, as noted above, many authors will at a minimum refer to the use of the seal as an alternative to consideration for the purpose of creating a binding contract at common law. ${ }^{77}$ To the extent that the contract itself is to be considered an agreement in the sense just described, it would seem to follow that the sealed instrument corresponds to, and may even be indissociable from, the existence of an agreement in its own right. The question that arises now, however, is precisely to what kind of agreement the sealed instrument should be taken to correspond: is it to be understood in terms of a largely executory agreement or "promise," or in terms of the already-completed agreement that complies with the structure of the gift as expounded above? Does it matter here whether the seal is used as a means of concluding a promissory arrangement or as an immediate transfer of tangible property rights?

As I want to suggest, it is the latter, executed or already-performed reading of the agreement concluded by means of a sealed instrument that provides the best explanation for

See e.g. Fuller, "Consideration and Form," supra note 4 at 820; Holmes, supra note 3; Waddams, supra note 9 at para 168; Benson, "Consideration," supra note 28 at 244. 
the manner in which this device operates. There are at least three features of the agreement concluded in this way that generally lend support to such a conclusion. The first is the unilateral — as opposed to bilateral — nature of the transaction, which largely mirrors the structure of the executed gift at common law by nonetheless requiring not only the delivery of the sealed instrument, but also the acceptance of the offer contained within it at the moment in which the instrument itself is delivered. The second feature, meanwhile, pertains to the limited types of conditions that can be attached to the effects of such delivery, and which also largely mirror the conditions that can be validly attached to the delivery of gift property. Finally, the agreement concluded by means of a sealed instrument is generally permitted to supersede an existing consideration-based promise even without the supply of additional consideration, a state of affairs that can be accounted for on the basis of it amounting to the performance that was promised under the original contract.

To begin with the unilateral nature of the agreement concluded by means of sealed instrument, this particular feature is largely apparent even on the face of the transaction: it is, after all, precisely because the agreement is concluded in this way, requiring the active participation of only one party, rather than the supply of consideration from both promisor and promisee, that it presents such a fundamental conceptual problem for the consideration or exchange-based view of contract in particular. ${ }^{78}$ As Benson notes in his own defence of the consideration requirement, however, the very form of the sealed instrument also appears to impose a kind of fundamental unilaterality that is absent in - and in fact contrary to the bilateral contract backed by consideration as exchange. ${ }^{79}$ This is because an agreement formed by means of a sealed instrument requires the instrument-making party to sign, seal, and deliver the instrument itself. ${ }^{80}$

On this reading, bilateral, "exchange"-like obligations can only be created by means of a sealed instrument if each of the parties have signed, sealed, and delivered their own respective documents - and thus respectively bound themselves in a unilateral manner to the other. ${ }^{81}$ Even in these cases, however, we might doubt whether the separate promises delivered by each party by means of a sealed instrument will truly have the same effect as a consideration-based contract, particularly where one party has failed to perform her end of the bargain. Whereas it is the essence of a consideration-based contract that one party's promise has been induced by the other's corresponding promise or act of performance, such that one party's failure to perform her end of the bargain may reduce or even fully excuse the other's correlative obligations, here the promises undertaken by each party are fully binding on their own by virtue of being made under seal — and, we can surmise, will generally remain so even if the other party is in breach of her own obligations. ${ }^{82}$

See the discussion in Part II, above.

Benson, "Consideration," supra note 28 at 245-46.

Friedmann, supra note 5 at 36. See also Restatement (Second), supra note 3.

The Exchange Bank of Yarmouth $v$ Blethen, [1885] UKPC 7 [Blethen]; Wilkinson $v$ The AngloCalifornian Gold Mining Company (1852), 118 ER 275 at 276-77 [Wilkinson]. Even the cosignatories of a sealed instrument are not bound by it unless they have each executed it on an individual basis: see Molsons Bankv Cranston (1918), 44 OLR 58 (CA); Scandinavian American National Bankv Kneeland (1914), 8 WWR 61 (SCC).

82 In this sense, the failure by one party to perform may not be excused by the corresponding nonperformance of an essential term or "condition" of the contract, a rule that may even apply where the parties have also supplied consideration in addition to conferring their undertakings under seal: see Davidson v Norstrant (1921), 61 SCR 493 at 504, Idington J (suggesting that notwithstanding the supply of consideration in the form of a reciprocal promise by the promisee, "when the contract for an option, as here, is under seal and purports to bind for a specific time, assented to by the covenantee, it binds without the payment of any consideration"). 
Stated differently, the completion of an agreement by means of a sealed instrument delivered to its intended recipient appears to bind the instrument-maker immediately and independently to the result intended by that instrument. That result may include the immediate transfer of particular property, or else the creation of an obligation that requires further future performance on the part of the instrument-maker. ${ }^{83}$ In either case, the question of precisely what was intended to be accomplished by delivery of the sealed instrument further remains, as in the case of the executed gift, tied primarily, if not exclusively, to the unilateral intention of the instrument-maker as determined at the moment of delivery. ${ }^{84}$ The recipient's physical acceptance of the instrument implies for its part acceptance of the instrument-maker's underlying offer and serves to conclude the agreement, unless a contrary intention is expressed. ${ }^{85}$ As Fuller himself appears to have recognized, the recipient effectively has no choice but to accept the agreement concluded by means of a sealed instrument on its face, with all the terms attached to it, or reject the instrument and the underlying agreement entirely. ${ }^{86}$

Further confirmation that the agreement concluded by means of a sealed instrument is both unilateral and immediately executed in at least some sense can be found in the limited types of conditions that can be validly attached to it by the instrument-maker at the moment of its conclusion through delivery. As in the case of the executed gift, an agreement formed by means of such a device must produce its effects immediately - either by transferring property or else creating an immediately binding obligation - or else have no effect at all. ${ }^{87}$ The sole exception to this rule is where the sealed instrument can be considered to have been delivered as an "escrow" - that is, as an instrument delivered subject to conditions under which it will take effect and become binding upon the parties. ${ }^{88}$ However, these conditions remain subject to the same underlying rationale as the donatio mortis causa and the gift made in contemplation of marriage, in that they are only validly admissible for the creation of an escrow if they are based on the occurrence of future events that are outside the control of the instrument-maker. Where the latter conserves the power to revoke the escrow, that power may invalidate the escrow as a whole. ${ }^{89}$

As in the case of the executed gift, the ultimate criterion that appears to be applied at common law to determine the validity of a sealed instrument thus appears to be one of control. In delivering the instrument, the instrument-maker must immediately divest herself of control over the rights set out in the instrument itself, even if the underlying agreement is

83 This latter result can be understood to reflect the delivery of an otherwise intangible right to demand future performance; I will have more to say on this point in Part IV.B, below.

$84 \quad$ Zwicker v Zwicker (1899), 29 SCR 527 [Zwicker]; Canadian Bank of Commerce v Dembeck (1929), 24 Sask LR 186 (CA). See also West Cumberland Iron \& Steel Co v Winnipeg (1890), 6 Man R 388 (CA) (holding that the expressed intent to "deposit" the sealed instrument upon physical delivery of the document suggests the existence of a bailment rather than a transfer of ownership).

85 See e.g. Re Rowan and Eaton (1927), 60 OLR 245 (CA) (holding that "[t]he deed to [the purchaser] is registered, and, in the absence of evidence to the contrary, the presumption is that he, as purchaser, caused such registration" at 250 ).

$86 \quad$ Fuller, Basic Contract, supra note 34 at 316-17.

87 Wilkinson, supra note 81 at 276-77; Blethen, supra note 81 at 298. But see Blethen, ibid at 299 (suggesting that the imposition of a condition subsequent does not bar the full execution of a sealed instrument).

88 See Governors and Guardians of the Foundling Hospital v Crane, [1911] 2 KB 367 at 374 (CA), Vaughan Williams LJ.

89 Ibid at 375, 379, 381. See also Graham v Graham (1791), 30 ER 339 (Exch); Hebert v Gallien, [1931] 2 DLR 150 (NBSC (AD)). 
not intended to take effect until the occurrence of some specified future event. ${ }^{90}$ Only under these circumstances will the sealed instrument validly take effect as an escrow, in the same way that a conditional gift may nonetheless be effective so long as the donor has divested herself of control over the gift property. If the effects of the instrument instead remain contingent on the instrument-maker's subsequent performance of some condition, which is required to either transfer property or create a binding obligation, then the underlying agreement will not be enforceable at all. ${ }^{91}$

Framed in these terms, it is apparent that the form of the sealed instrument corresponds not only to a necessarily unilateral agreement, but also to a necessarily executed agreement, in the sense that it must be performed at the very moment it comes into existence in order to be enforceable. This much is particularly apparent in those cases where the instrument serves as a deed of transfer - which is to say, when it serves to transfer particular property, and real property in particular. In those cases, the answer given to the question of whether the instrument has been fully executed as a deed will also generally resolve that of whether the transferee has been made the full owner of the property in question, much in the same way that delivery serves to complete the transfer of ownership from the donor to the donee in the context of an executed gift. ${ }^{92}$ The same can be said, however, of the sealed instrument that serves not to effect an immediate transfer of property, but rather to create a binding future obligation - which is to say, a "promise."

I will have more to say about the role of the sealed instrument as a means of creating a promissory arrangement analogous to a consideration-based contract below. Before turning to this particular issue, however, there is one final feature of the agreement concluded by means of a sealed instrument that further supports its status as an immediately performed agreement modelled on the executed gift, and which is worth some consideration in its own right. This feature corresponds to the possibility that a sealed instrument be used to complete — and potentially supersede - a pre-existing agreement between the same parties, and is also known simply as the doctrine of "merger." 93 Most strikingly, merger is specifically contemplated to operate in the presence of an already-enforceable executory agreement backed by consideration. ${ }^{94}$

$90 \quad$ See Doe d Garnons v Knight (1826), 108 ER 250 at 257-58 (KB). Compare Walker, supra note 56 at 301.

91 Such a condition would usually imply that the instrument-maker has retained the power to revoke the instrument made in escrow, contrary to the rule set out in the above-cited decisions; the further implication here is that unlike a parole promise or promise otherwise backed by consideration, even a "promise" made in the form of a sealed instrument must be immediately binding upon the instrumentmaker, or else be subject to a condition that is outside of her control.

92 See e.g. Conyers v Orr (1943), [1944] 1 DLR 201 at 202 (" $[\mathrm{t}]$ he neat point for decision is whether the conveyance in question took effect as a deed of gift immediately upon its execution or whether Margaret Orr intended to retain the ownership of the property until her death — in other words, was the document a deed or a testament?"). This conclusion is of course subject to the caveat that transfers of real property (and of some forms of personal property) must also be registered in some jurisdictions.

93 There is some controversy as to whether the use of a sealed instrument actually replaces the pre-existing agreement entirely, or only serves to perform some of its aspects: see Waddams, supra note 9 at para 327. The answer to this question is largely immaterial for the purposes of this article, as it is clear in either case that the sealed instrument serves as a means of rendering performance of one party's alreadyassumed obligations.

$94 \quad$ See Knight Sugar Co v Alberta Railway \& Irrigation Co (1937), [1938] 1 DLR 321 (PC). Compare the "dation en paiement" recognized by some civilian legal systems, which is a contract by which a party undertakes to perform an existing obligation through the immediate delivery of property: see e.g. arts 1799-1801 CCQ. 
While the doctrine of merger might be explained away relatively easily by positing a preference at common law for formal, sealed agreements over informal contracts backed by consideration, this explanation remains largely incomplete on the whole. Under this view, the use of a sealed instrument would seem to allow for the enforcement of a subsequently concluded agreement over a parole-based contract backed by consideration because the former is given greater standing and recognition by the common law. The problem here, of course, is that this argument does not tell us why the common law holds such a preference - or more importantly, how it remains justified in doing so when the continued relevance of the seal itself has increasingly come under scrutiny.

To this issue, we can add that the doctrine of merger also appears to contradict both the policy and formal rationales that underlie the common law's traditional refusal to enforce contractual modifications made without the supply of fresh consideration. ${ }^{95}$ How, we might ask, does the fact of compliance with this kind of formality relieve a party from complying with the rule, or else dispel any doubts that might exist as to the coercive force that may have been exercised by one party to procure the modified set of obligations ? $^{96}$

The answer here, I want to suggest, can be found in what has traditionally been an exception to the rule requiring fresh consideration to conclude a new bargain - that is, namely, the rule that allows the parties to transact upon or settle an existing or even future dispute without supplying fresh consideration in return. ${ }^{97}$ The determinative criterion here appears to be that the settlement or release in question must amount to a full and final performance of the parties' respective obligations under the existing contract, such that a settlement by which one party undertakes a new promise will not normally survive the application of the fresh consideration rule. ${ }^{98}$ Tellingly, such immediate performance can be considered to have been rendered — and a full and final settlement reached — where a party provides payment in the form of a cheque or bill of exchange, even if the bill itself only amounts to the physical embodiment of the right to receive payment in the future. ${ }^{99}$ And, of course, the use of a sealed instrument is likewise generally admitted for such purposes. ${ }^{100}$

This last scenario provides us with what is perhaps the best basis on which we can understand the operation of the sealed instrument generally, and the doctrine of merger in particular. As with the executed gift, the sealed instrument appears to embody a distinct, selfcontained agreement by which the instrument-maker unilaterally performs a transfer of rights — and in so doing may also perform an existing promise. Rather than altering the existing promissory relationship between the parties in a way that contravenes the fresh consideration rule, the instrument-maker thus completes the existing promissory agreement by tendering an alternative performance, which is then accepted by the recipient. The chief difference with the gift is that the prior promise in question may constitute a legally binding obligation or

95 See most notably Stilk v Myrick, [1809] EWHC KB J58.

The latter criterion has, of course, become much more important in recent years as the rigidity of the traditional rule has been called into question in Canada and elsewhere: see e.g. Williams v Roffey Brothers \& Nicholls (Contractors) Ltd, [1989] EWCA Civ 5; Greater Fredericton Airport Authority Inc $v$ NAV Canada, 2008 NBCA 28; Rosas v Toca, 2018 BCCA 191.

97 See e.g. Attorney General of British Columbia $v$ Deeks Sand \& Gravel Company Limited, [1956] SCR 336.

Foakes v Beer, [1884] UKHL 1 [Foakes].

Sibree v Tripp (1846), 153 ER 745 at 751-52; Foot $v$ Rawlings, [1963] SCR 197.

Foakes, supra note 98, Earl of Selborne LC. See also Blethen, supra note 81; Chilliback v Pawliuk (1956), 1 DLR (2d) 611 (Alta SC) [Chilliback]. 
contract in its own right and - following the bill of exchange example just mentioned above - is potentially replaced through the medium of the sealed instrument not with a completed transfer of property rights, but rather with a second, fully enforceable promissory obligation.

\section{B. Performance ANd Sealed InSTRUments}

Having now argued that an agreement concluded by means of a sealed instrument is both necessarily unilateral and immediately performed at the moment of its conclusion, the final question that remains to be answered pertains to why compliance with the form of the sealed instrument is capable of achieving the effects that $I$ have so far ascribed to it - which is to say, why it serves as both a means of transferring certain kinds of property rights and of creating promissory obligations.

Consistent with my overall argument, I want to now suggest that the dual function of a sealed can be explained by reference to the form of the instrument itself, as a medium through which the intention to immediately perform a transfer is communicated. As with the delivery of gift property, and as already mentioned above, the delivery of the sealed instrument must be intended to take immediate effect in order to validly count as such. ${ }^{101}$ To the extent that this is the case, the delivery of a sealed instrument serves to mark the point of simultaneous offer, acceptance, and performance in precisely the same manner as the delivery of gift property in the case of an executed gift. However, and by contrast to the delivery of gift property, the form of a written instrument also allows the sealed instrument to signify a range of meaning that is not strictly possible by way of physical delivery. These additional meanings include the transfer of both real property rights and of incorporeal rights, the latter in a manner that at least superficially resembles the creation of a future obligation. $^{102}$

This emphasis on the role of the sealed instrument qua written instrument serves to complete Brudner's suggestion that the delivery of a deed under seal should be understood as a particular kind of symbolic delivery. ${ }^{103}$ Taken on its own, the strength of Brudner's argument is particularly apparent in cases where the instrument properly amounts to a deed, and is thus used as an alternative for the actual, physical delivery of real property including cases where the real property is being conveyed gratuitously, as a gift. ${ }^{104}$ Since this class of thing is usually incapable of physical delivery, it is reasonable to expect that some

101 See the discussion in Part IV.A, above, and especially Blethen, supra note 81 at 298; Wilkinson, supra note 81 at $276-77$.

102 In theory, this means that a whole number of conditions and additional rights can be attached to those rights conveyed by way of sealed instrument, including warranties and restrictive conditions imposed on the receipt of transferred property (for example, a "restrictive covenant"); the form of the sealed instrument can also be used as a means of providing a release: see e.g. Blethen, supra note 81; Chiliback, supra note 100 .

103 Brudner \& Nadler, supra note 6 at 199.

104 See e.g. McGee v Lewis (1966), 59 DLR (2d) 362 (Alta SC (AD)), aff'd (1967), 65 DLR (2d) 672 (SCC) (holding that the gift of a house was incomplete because the sealed instrument had never been delivered); Royal Trust Co v Eldridge, [1923] 2 DLR 689 (holding that a father's purchase of property in his son's name, without his son's knowledge and without registering the interest in his son's name, was effective as a gift upon the son's acceptance of the sealed instrument even after his father's death). 
alternative device — for example, a deed under seal — might serve to complete the transaction instead. ${ }^{105}$

To these arguments, we can add that the purpose that is normally served by the physical delivery of the gift property from the perspective of third parties - who are at the very least provided a way of knowing, if not outright knowledge, that the transfer of rights has occurred - is also met in these cases by the delivery of a physical document. In the absence of a registration system, a public ceremony, or the actual occupation of the land in question the latter perhaps not being conclusive of ownership in any event, particularly in light of the feudal history of the common law - physical delivery of the instrument that evinces a transfer of title to the real property at issue probably amounts to the next best way by which such notice can be provided to third parties. ${ }^{106}$

By contrast, the scenario in which the sealed instrument is used to create a form of promissory obligation - or at least an arrangement that appears very similar to one presents more difficulty, especially if one adopts an exchange-based view of contract. How do we account for such a possibility, particularly given my previous argument to the effect that the sealed instrument corresponds to a necessarily performed agreement, rather than an agreement to render future performance? This question appears particularly important in light of the seal's apparent historical genesis as a means of generating an ostensibly contractual relationship rooted in promissory liability, rather than an immediate transfer of property rights in the manner just described. ${ }^{107}$

The explanation for this second type of transaction concluded by means of a sealed instrument requires that we distinguish the agreement that serves to transfer particular rights - here performed by delivery of the instrument itself — and the nature of the right being transferred, which may be such that the instrument-maker is required to render further performance to the recipient at some point in the future. The relatively unique feature of the sealed instrument in this respect is that it combines both a means through which this underlying agreement can be concluded and performed, on the one hand, and the additional flexibility provided by the written form to transfer all sorts of rights - including completely intangible in personam rights to demand the future performance of some particular act.

Of course, this last feature of the sealed instrument is not exclusive to the class of transaction just described either. There is another type of document recognized by the common law that has already been mentioned above, and which can be taken to largely serve the same function: the bill of exchange. The bill, like the sealed instrument, should not be taken in a manner that is synonymous with the agreement that serves to transfer it. It is instead treated for all intents and purposes as a "good" — which is to say, as the physical

105 This function was historically performed by means of a special livery of seisin ceremony, but appears to have been superseded by the use of sealed instruments following the enactment of the Statute of Uses (UK), 1535-36, 27 Hen 8, c 10 (namely, by using a sealed instrument to immediately transfer a use, which the use-breaking provisions of the statute sanctioned by transforming into an immediate transfer in fee simple).

106 As previously mentioned, most modern common law legal systems will take this function of the deed one step further by requiring that it be registered either as a condition of enforcement against third parties, as in a deed registration system, or as a transfer of title in the first place, as in most modern Torrens title systems: see e.g. Ontario's Land Titles Act, RSO 1990, c L.5 and New Zealand's Land Transfer Act 2017 (NZ), 2017/30. 
embodiment of what would otherwise constitute an intangible asset, namely the right to obtain payment. ${ }^{108}$ It follows that the bill can be transferred in precisely the same way as any other tangible thing - including, most notably for our present purposes, by means of a gift performed through delivery, a possibility which has been characterized simply as a gift of negotiable instrument. ${ }^{109}$ In such cases, the agreement would be precisely in the form outlined above, the only difference being that the gift property at issue corresponds to the physical embodiment of an intangible right to demand payment. ${ }^{110}$

At the same time, there are important differences between the sealed instrument and the bill of exchange that should not be overlooked, and which largely account for the different treatment that is accorded to these two types of arrangements. The sealed instrument can, for example, embody more than simply the right to obtain payment — it is, again, a "blanket formality" that serves to make virtually any type of agreement enforceable. The rights conferred by means of a sealed instrument are also not freely assignable — and are certainly less so than the bill of exchange that confers a right to obtain payment upon anyone, save for a holder in due course, who legally gains possession of the bill instrument. ${ }^{111}$

These differences can largely be explained by the nature of the instruments themselves: whereas the bill is by its nature intended to be freely assignable, and the bill itself can be taken in a sense to count as a form of "property," the sealed instrument remains tied to the initial transfer of a particular asset or right. The bill of exchange can be equated with the right to obtain payment to which it gives corporeal existence, and can be freely transferred by its present owner in the same way as any asset or good. Its delivery accordingly does not amount to a form of symbolic delivery at all, but rather to the actual, physical delivery of the right, which the bill serves to physically embody. The sealed instrument instead appears to simply constitute a vehicle or medium by which one person symbolically delivers and thus transfers a particular right to another determined person. Once the transfer is complete, the continued existence of the sealed instrument only evinces the fact of this prior performance and transfer, such that its destruction does not invalidate the underlying transaction. ${ }^{12}$ The underlying agreement likewise continues to exist even if the instrument is returned to the instrument-maker after its execution. ${ }^{113}$

Stated differently, we can affirm that there exists a certain degree of overlap in the effects of the bill's original delivery and that of a sealed instrument. Both can be taken in this context to "create" new rights insofar as they generate a new legal relationship (an

108 Marfani \& Co Ltd v Midland Bank Ltd (1967), [1968] 1 WLR 956 at 970 (CA), Diplock LJ.

109 See e.g. Lumsden v Miller (1980), 110 DLR (3d) 226 (Alta QB) (held that cheque given to daughter by deceased constituted a valid donatio mortis causa).

110 The future-oriented nature of this right is consistent with some cases involving the gift of a cheque; while the gift of the physical cheque instrument may be completed by its delivery, the gift of the money itself may not be complete until the cheque has been cleared by the receiving bank: see e.g. $R e$ Loipersbeck Estate (1998), 133 Man R (2d) 289 (QB).

111 This rule is codified: see e.g. Bills of Exchange Act, 1882 (UK), 45 \& 46 Vict, c 61, s 38; Bills of Exchange Act, RSC 1985, c B-4, s 73. By contrast, the right to claim or be claimed against on a sealed instrument are both limited to parties named in the instrument itself - a rule that goes so far as to exclude the enforcement by and against undisclosed principals: see Friedmann, supra note 5.

112 Doe d Ellis v McGill (1850), 8 UCQB 224. This conclusion is largely consistent with Simpson's historical account of the sealed instrument as an essentially evidentiary rather than dispositive device: see Simpson, supra note 31 at 15.

113 See Zwicker, supra note 84 (an agreement concluded by sealed instrument can be validly enforced even if the instrument is retained by the promisor after execution). Contrast Rayner $v$ Read, [1943] 4 DLR 803 (SCC), aff'g [1943] 2 DLR 225 (PEISC) (the return of gift property by the donee to the donor for safekeeping does not invalidate the gift). 
obligation) between the parties where none existed before. The main difference, however, lies at the level of what can be done with that relationship once it has been established. Since the bill constitutes the physical embodiment of the right, the right that it bears is freely assignable in the proper sense of the term: while no new obligation is created, the identity of the right-bearer can, in this way, be changed on an ongoing basis until the right itself is exercised.

In the case of a sealed instrument, by contrast, we can conclude from the foregoing that its status as a blanket formality can be largely attributed to its use as a written instrument that can serve to symbolically represent or "stand in" for virtually any type of right. Often, this means that the sealed instrument will be used as a deed to transfer real property by what amounts to symbolic means - a state of affairs that explains the colloquial association of the term "deed" with the conveyance of an interest in land. ${ }^{114}$ However, these cases do not exhaust the potential application of the sealed instrument. Where the right corresponds to an obligation to render future performance, it is the right itself as represented by the instrument that is delivered and transferred to the recipient of the instrument in a unilateral transfer which is to say, in effect, that the "promise" is gifted by the promisor to the promisee by what amounts to symbolic means.

\section{CONCLUSION}

In this article, I have argued that the agreement concluded by means of a sealed instrument should be understood not by analogy to consideration-based contracts, but as a unilateral transfer similar to the executed gift. Rather than being tied to the intrinsically executory notion of "promise," the sealed instrument should thus be conceptualized as a particular way by which an agreement to transfer rights — whether in rem or in personam — can be performed at the very same moment in which that agreement is concluded. I have further suggested that this type of arrangement should be understood to correspond to a selfcontained agreement that is separate from, but may be completed in performance of, an already-existing executory agreement or promise that requires such rights to be transferred.

By framing the sealed instrument in these terms, I hope to have provided a compelling basis for understanding a particularly thorny - though often marginalized - feature of the common law of contracts. While both authors who defend consideration as exchange and those who reject its relevance to contract law have typically sought to exclude the effects of sealed instruments from their discussions, my purpose above has been to show how it can be fruitfully integrated into a theory of contract that distinguishes executory and executed (in the sense of already-performed) agreements. On my reading, the latter class corresponds to agreements to immediately give and to receive a given right — whether that right has previously been made subject to a promise or not — and likely encompasses a number of additional types of "formal" contracts still recognized by the common law. ${ }^{115}$

114 See Town of Eastview v Roman Catholic Episcopal Corporation of Ottawa (1918), 44 OLR 284 at 295 (SC) (stating that " $[\mathrm{w}]$ hile in technical language any document under seal ... is a 'deed,' the word 'deed' is most frequently used in the popular sense of a conveyance of real estate").

115 Examples cited above include gifts, bailments, and negotiable instruments, but additional types of agreement can undoubtedly be conceptualized in similar terms. 
This conclusion opens the door to a number of additional lines of inquiry. First and foremost, it allows us to break free from the association of both delivery and the seal with the other formalities outlined in Fuller's now-classic article, "Consideration and Form."116 Viewed in light of my argument, consideration applies to an entirely different class of agreement - the executory contract — which allows the promisee to demand the performance of a promise without a prior executed agreement. ${ }^{117}$ By contrast, both gifts completed by means of delivery and formal contracts like those completed under seal appear to correspond primarily - and perhaps even exclusively — to the category of agreements that are performed immediately upon their conclusion, and that accordingly effect a transfer of property or other, similar kinds of rights. ${ }^{118}$ The question of whether consideration is or should be required to conclude a valid promise is, on this reading, largely immaterial to the place of either uses of sealed instruments within the common law tradition: these devices are first and foremost means of transferring property rights, not concluding promises - even as they may also be used to create binding promises of future performance in their own right. ${ }^{119}$

At the same time, it can also be queried whether the foregoing account of the sealed instrument can serve to offer a coherent defence of the seal qua seal, rather than of the written instrument with which this formality has historically been associated. To the extent that such a question can be answered in a summary fashion, it must, I think, receive a negative response given the emphasis above on the medium of the written instrument rather than the seal itself - as a specific, substantive requirement to complete a transfer of rights. That said, the seal may may nonetheless retain value as a means of indicating the intention to conclude a particular type of written agreement, and perhaps particularly for the purpose of distinguishing a promissory note or bill of exchange from a transfer of intangible rights that are not meant to be freely assignable after the transfer is complete. ${ }^{120}$

Finally, the conclusion drawn in this article with respect to the sealed instrument and its relationship with gifts and consideration-based contracts likely requires that we confront the nature and boundaries of contract law itself — at least in the manner in which that term is

116 To borrow Fuller's phrasing, delivery and the use of sealed instruments can be understood as "natural formalities" that apply to these types of transfers, by contrast to those "on which the courts might seize as a test of enforceability" for contracts generally, a possibility which Fuller expressly denies: Fuller, "Consideration and Form," supra note 4 at 815.

117 My conclusion in this respect is consistent with those of both Peter Benson and Alan Brudner: see Benson, "Consideration," supra note 28 at 246; Brudner \& Nadler, supra note 6 at 199.

118 This view of the relationship between gifts and sealed instruments can be understood to correspond to both the broader notion of a "real contract" and Kant's pactum rei initium, which amounts to a selfcontained agreement that is necessary in order to perform - and thus complete — any already-existing executory agreement pertaining to a transfer of acquired rights: see supra notes 36-37 and accompanying text.

119 It follows from this conclusion that the theoretical necessity of the sealed instrument in performing this second function remains largely contingent on whether consideration is understood as an essential element of a binding contract generally; even if we conclude that it is not, we may nonetheless affirm the theoretical necessity (rather than simply practical utility) of the sealed instrument insofar as it also serves as a means by which full in rem rights can be transferred in performance of an existing contractual obligation.

120 In this respect, my answer may well be compatible with those of Fuller and other authors insofar as they favour the abolition of the seal itself, but not sealed instruments; that said, the potential relevance of the seal for the purpose of distinguishing written instruments used to conclude a valid promise between two defined parties and those which are used to constitute bills of exchange may explain why it remains in force for these purposes, even as it has been abolished in relation to real property transfers in many jurisdictions. 
usually understood in common law sources. ${ }^{121}$ We can ask, for example, whether the agreement concluded by means of a sealed instrument constitutes a "contract," even if the medium serves as both a means of creating future promises and immediately conveying property rights. By contrast to the previous question, it appears that the answer to be given here must be affirmative, at least in the former case - though it should perhaps be negative in the latter, where the sealed instrument is used simply as a means of transferring property. What serves to set the promise concluded by means of a sealed instrument apart from the latter type of operation in particular, and that ultimately affirms the status of the promise under seal as a proper contract in the common law sense of the term, lies perhaps in the fact that the instrument-maker acts in these cases not just as transferor, but also as promisor: not only can she be understood to transfer an intangible right that entitles the transferee to demand future performance, but she is also assuming a correlative duty - which is to say, obligating herself — to provide that performance, rather than simply transferring the right outright, without undertaking any future duties of her own.

121 As implied above, civil law generally has a broader understanding of contract that is focused solely on existence of agreement, regardless of whether it is gratuitous or onerous or of immediate or future performance: see e.g. art $1378 \mathrm{CCQ}$. 